Rodzina, ekonomia i migracja. Ujęcie prawne i socjologiczno-ekonomiczne, red. Magdalena Butrymowicz, Piotr Kroczek, Kraków 2021, s. 29-48 (Biblioteczka Prawa, 4).

ks. Łukasz Marczak

https://orcid.org/oooo-0003-1553-1747

UNIWERSYTET PAPIESKI JANA PAWŁA II W KRAKOWIE

\title{
Transmisja wartości rodziny w perspektywie realizacji zrównoważonego rozwoju
}

\section{Wstęp}

Pojęcia, takie jak rodzina i zrównoważony rozwój występują w życiu społecznym powszechnie i w związku z tym są różnorodnie rozumiane. Semantyka tych pojęć jest bardzo ciekawa, ukazuje ich odmienne znaczenia w różnych kontekstach. Opis relacji między językiem a rzeczywistością może zmieniać znaczenie rodziny w życiu społecznym, które poddane zostało realizacji celów zrównoważonego rozwoju. Rozumienie podstawowych kategorii życia społecznego ma znaczenie $\mathrm{w}$ realizacji polityk społecznych, które z różnym natężeniem wpływają na kondycję rodziny. Stąd wobec realizacji polityk zrównoważonego rozwoju wydaje się, że z punktu widzenia socjologicznego nigdy nie wyczerpuje się potrzeba analizy dot. kondycji rodziny i transferu tej wartości w systemach społecznych i gospodarczych, zwłaszcza 
w kontekście starzenia się społeczeństw i wzrostu zainteresowania trendami ekologicznymi w gospodarce i codziennych praktykach.

Opracowanie ma na celu ukazać transmisję wartości rodziny w procesie realizacji zrównoważonego rozwoju. Najpierw dokona się rozróżnienia pomiędzy ideą, polityką a zasadą etyczno-społeczną w kontekście kategorii zrównoważony rozwój. Następnie wskaże się wartość rodziny w perspektywie analizy społeczno-prawnej dotyczącej realizacji celów zrównoważonego rozwoju, po czym przejdzie się do przedstawienia statusu zasady zrównoważonego rozwoju i jej zastosowania. Narrację zogniskuje się wokół odpowiedzi na pytanie: jak realizacja zrównoważonego rozwoju może wzmacniać rodzinę? Jedną z możliwości jest program ukierunkowania celów zrównoważonego rozwoju na koncepcję dobra wspólnego. Niezbędny jest do tego spójny system zasad etyczno-społecznych, w oparciu o który można tworzyć strategie rozwoju społeczno-gospodarczego. Dla egzemplifikacji takiego działania przedstawi się ramowy program takiej strategii, którą wypracowali Matthias Kasper i Gerd Hofielen.

Ze względu na wyzwanie systemowego balansowania płaszczyznami dobra wspólnego perspektywa niemieckich badaczy think tanku Humanistic Management Practices gGmbH z Berlina wydaje się adekwatna do współczesnych strategii rozwojowych. Gerd Hofielen jest ekspertem zarządzania przedsiębiorstwem w uwarunkowaniach wielokulturowości. Matthias Kasper specjalizuje się w edukacji alternatywnych form gospodarowania ukierunkowanego na współzależność społeczno-środowiskową. Strategia podlega ocenie etycznej.

\section{Zrównoważony rozwój - ideologia i polityka a zasada etyczno-społeczna}

Życie społeczne charakteryzuje przenikanie się systemów wartości i ich modyfikacja. Transmisja wartości zachodzi ze względu na 
występowanie różnorodnych przyczyn, które mają wpływ na większą dominację jednych systemów wartości nad pozostałymi. Transmisja wartości jest typowa dla funkcjonowania zróżnicowanych aksjologicznie społeczeństw, w których innowacyjność zwiększa znaczenie niektórych wartości ze względu na ich realizację. Wartości z punktu nauk socjologicznych rozumie się jako „zinternalizowane standardy zachowań odziedziczone przez osoby $\mathrm{w}$ procesie socjalizacji w kulturowym kontekście określonego społeczeństwa"

Kategorię zrównoważony rozwój jako zjawisko aksjologiczne ujmuje się jako wartość idealną, jako standard modelowy, wzorcowy. $Z$ jednej strony wartość idealna jest niemożliwa do urzeczywistnienia, z drugiej strony wyznacza jednak kierunek dążeń człowieka. Ideał wskazuje zatem na wzorzec przewodni w realizacji celów, tzw. leitmotiv. Zrównoważony rozwój w złożoności celów i towarzyszących im wartości, w zakresie swojego oddziaływania tworzy ideologię, spajającą kultury w jej globalnym wymiarze, łączącą światopoglądy o charakterze międzypokoleniowym. Lokalny wymiar zrównoważonego rozwoju obejmuje dążenie do zabezpieczenia dobra państwa. Stąd zrównoważony rozwój jako ideologia ujmowany jest jako zbiór wiodących i dominujących idei skupiających w sobie ujęcia: polityczne, prawne, ekonomiczne, filozoficzne, społeczne, ekologiczne, a nawet religijne ${ }^{2}$.

Wartość idealna w realiach złożoności społeczno-gospodarczej i środowiskowej różni się więc od wartości możliwej - niezrealizowanej jeszcze, ale nadającej się do uskutecznienia ze względu na faktyczne uwarunkowania związane z występowaniem potrzeb ludzkich. Wartość idealna bądź idealistyczna różni się tym bardziej od wartości

1 W. Piwowarski, Socjologia religii, Lublin 1996, s. 242.

2 Por. Słownik socjologii i nauk społecznych, red. G. Marshall, Warszawa 2006, S. $122 \mathrm{n}$. 
faktycznej, która zyskała uznanie i została urzeczywistniona, wyrażając konkretny stan rzeczy³. Stąd wartość idealna znajduje swoje odzwierciedlenie $w$ realizowanej polityce, ujmowanej z punktu widzenia aksjologicznego w sensie troski o dobro wspólne. Do świata wartości należą wszystkie kategorie, którym przyznaje się wagę znaczeniową zwłaszcza pod względem naznaczającym całość społeczną. W ten krąg wlicza się także kategorię zrównoważonego rozwoju. Wartość pozytywną posiadają głównie wartości idealne i ideały, przez co w życiu społecznym rozumie się je jako dobra, do których jednostki społeczne dążą ze względu na postawę szacunku względem nich ${ }^{4}$. Zrównoważony rozwój jako idea gospodarowania, w którym zaspokojenie potrzeb obecnego pokolenia nie odbiera szans rozwoju przyszłym pokoleniom, posiada wartość pozytywną. Realizm realizowania takiej polityki jest już przedmiotem badań na polu wielu dyscyplin. W przejawach życia społecznego zauważa się zespół powiązanych funkcjonalnie norm i wartości, które tworzą całościowy system aksjonormatywny.

Idei poszukiwania balansu między systemami społecznymi i gospodarczymi przy uwzględnieniu jakości ekosystemów towarzyszy realnie prowadzona polityka, ogólnie definiowana jako realizacja celów skupiających się wokół rozwoju państwa przy wykorzystaniu odpowiednich do tego środków. Wartość idealna szuka więc ukonkretnienia w realizacji wspólnych dóbr przez władzę, której powołanie całościowo ma służyć kreacji ładu społecznego 5 . Dobra te są imperatywami normatywnymi i w realizacji polityk umożliwiają pełny, integralny rozwój człowieka. Wartość rozwoju od założenia

3 Por. W. Stróżewski, Transcendentalia $i$ wartości, w: W. Stróżewski, Istnienie i wartość, Kraków 1981, s. 90-95.

4 Por. J. Szczepański, Elementarne pojęcia socjologii, Warszawa 1963, s. 54.

5 Por. J. Mazur, Pro familia et societate. Wybrane zagadnienia polityki społecznej, Kraków 2013, s. 11. 
idealistycznego staje się wartością coraz bardziej faktyczną wraz $\mathrm{z}$ tworzeniem wartości wspólnych, będących środkami służącymi do realizacji celów osobowych ${ }^{6}$. W ten sposób drogą do rozwoju społecznego i osobowego każdej jednostki jest realizacja zasad etyczno-społecznych. Zasady te nie ulegają zmianie, istnieją odwiecznie i są wyłaniane w konkretnych uwarunkowaniach niesprzyjających integralnemu rozwojowi osobowemu ${ }^{7}$. Stąd idea znajduje urzeczywistnienie w polityce i w miarę niemożności realizacji celów podstawowych grup społecznych - służących także rozwojowi państwa - wyłania się zasady etyczno-społeczne stojące na straży wartości podstawowych nadających sens i identyczność jednostkom ludzkim, jak i całym społecznościom ${ }^{8}$. W kręgu tych wartości znajdują się: godność ludzka, życie, praca, własność prywatna, integralny rozwój. Życie społeczne składa się z wielu takich kategorii, pośród których znajduje się rodzina, powiązana z różnorodnymi systemami społecznymi, gospodarczymi i towarzyszącą im kulturą. Rodzina jest jedną z wielu grup społecznych i jednocześnie wartością podstawową ze względu na jej fundamentalne odniesienie do funkcjonowania państwa. Zapewnienie warunków do rozwoju rodziny staje się więc jedną z podstawowych funkcji polityki państwa.

\section{Wartość rodziny i cele zrównoważonego rozwoju}

Z punktu widzenia nauk socjologicznych w perspektywie polityk zrównoważonego rozwoju jednym z najbardziej eksplorowanych obszarów badań jest sytuacja demograficzna, która znacząco wpływa na politykę społeczną i stabilność gospodarki. Wraz z innowacyjnością

6 Por. W. Piwowarski, ABC katolickiej nauki społecznej, Pelplin 1993, s. 61-63.

7 Por. W. Piwowarski, ABC katolickiej nauki społecznej, dz. cyt., s. 61-63.

8 Por. W. Piwowarski, Socjologia religii, dz. cyt., s. 242. 
gospodarki ze względu na ewolucję kwestii ekologicznej istotne stają się uwarunkowania wzrostu udziału ludzi starszych w społeczeństwie ${ }^{9}$. Rodzina w otoczeniu społeczno-gospodarczym i środowiskowym wciąż pozostaje podstawową grupą społeczną, która ze względu na swą funkcjonalność wobec systemu społeczno-gospodarczego wymaga wsparcia. Tym bardziej jest to zauważalne w sytuacji, kiedy model rodziny w Polsce zmieni się choćby w wyniku procesu podwójnego starzenia się, wzrostu liczebności osób zaliczanych do kategorii później starości (powyżej 80. lub 85. roku życia) ${ }^{10}$. W sytuacji demograficznej Polski takim procesom, naznaczonym zwiększeniem występowania osób z orzeczonym stopniem niepełnosprawności (20\% w wieku powyżej 80 lat), towarzyszą wyznaczone w polityce globalnej cele zrównoważonego rozwoju.

Jeszcze bardziej uzasadnione jest wsparcie rodziny w przypadku jakichkolwiek niejasności semantycznych mogących wpłynąć na jej redefinicję i postrzeganie osób starszych czy dzieci w rodzinie. Ideologiczność programów rozwoju staje się tym bardziej zauważalna, gdy wraz z ich realizacją pojawiają się zjawiska społeczne powstałe wskutek redefinicji podstawowych kategorii społecznych, których konsekwencją jest marginalizacja osób w tzw. wieku nieprodukcyjnym, dzieci lub osób starszych. Zmiana rozumienia rodziny i dywersyfikacja modeli rodzin jest już faktem i domaga się nie tylko wskazania przyczyn takiego stanu, ale także strategii wyjścia charakteryzujących się podjęciem konkretnego działania, przyjęcia odpowiedniej antropologii społecznej. Jest ona niezbędna wobec pojawiających się

9 Por. A. Świerczek, Rodzina w kontekście kryzysu demograficznego w Polsce, w: Aspekty teoretyczne i praktyczne w pracy socjalnej wobec przemian $i$ wyzwań społecznych XXI wieku, red. M. Duda, L. Szot, A. Świerczek, t. 2, Kraków 2017, s. 56-6o.

10 Por. R. Iwański, Opieka długoterminowa nad osobami starszymi, Warszawa 2017, s. 75 . 
rodzin zatomizowanych, patchworkowych czy związków jednopłciowych. Zdaniem Michała Gierycza w ujęciu praw podstawowych uE dokonano redefinicji fundamentalnych prawnomiędzynarodowych przesłanek antropologicznych w odniesieniu do relacji osoby, małżeństwa oraz rodziny, co zadecydowało o rozumieniu natury człowieka. Takie zjawisko utrudnia lub całkowicie uniemożliwia realizację polityki rodzinnej na poziomie $\mathrm{UE}^{11}$. Ukierunkowanie procesu wsparcia rodziny odpowiadałoby unieważnianiu niektórych tradycyjnych idei i wartości, wśród których znajduje się rodzina obejmująca wszystkie kategorie wiekowe jednostek przynależących do tej grupy społecznej. Proces unieważniania tradycyjnych wartości charakteryzuje politykę opartą na antropologii nieograniczonej, która z jednej strony redukuje status człowieka (do poziomu zwierząt, roślin czy bytów nieożywionych), a z drugiej strony absolutyzuje go, czyniąc zeń najwyższą istotę stworzonego świata i jedynego jego autokreatora. $\mathrm{W}$ tak rozumianym świecie wiodącą rolę odgrywają ludzie silni i aktywni w życiu społecznym. Ludzie najstarsi lub jeszcze nienarodzeni mogą zostać w ideologicznych działaniach na rzecz zrównoważonego rozwoju zmarginalizowani, a ich status w zakresie tzw. zdrowia reprodukcyjnego niekiedy bywa niżej klasyfikowany niż jednostek społecznych pozostających w sile wieku.

Redefinicja rodziny dokonała się już marksistowskiej teorii prawa, które zniosło moralne ograniczenia natury ludzkiej i wyzwoliło w człowieku nieograniczony potencjał samowyzwolenia się z dotychczasowych norm cechujących religię chrześcijańską i tradycję ukształtowaną wskutek procesów socjalizacyjnych charakteryzujących religię. Gierycz określa ten proces apogeum elastyczności prawa, które prowadzi

11 Zob. M. Gierycz, Unii europejskiej (re)definicja małżeństwa i rodziny. Antropologiczne i polityczne znaczenie w kontekście starzenia się Europy, „Annales Universitatis Mariae Curie-Skłodowska” 22 (2015) nr 2, s. 69-83. 
do formułowania polityk będących próbą realizacji ładu społecznego opartego na nowych, zredefiniowanych kategoriach społecznych ${ }^{12}$. Proces ten - jak twierdzi Marguerite A. Peeters - doprowadza do dekonstrukcji wartości chrześcijańskich w imię tworzonej nowej, zsekularyzowanej etyki ${ }^{13}$. Jej egzemplifikacją są nieantropocentryczne etyki środowiskowe. Przez dekonstrukcję podstawowych, klasycznych kategorii społecznych rozumie się tutaj rozwarstwienie semiotycznej budowy języka w celu przekształcenia sensu kategorii powszechnie używanych w życiu społecznym, zarówno w normach prawa, jak i w języku potocznym. Wynikiem zdekonstruowanej rzeczywistości społecznej są nowe paradygmaty życia społeczno-gospodarczego i społeczno-ekologicznego, które mają na celu tworzyć nową kulturę, w dużej mierze silnie skorelowaną i poddaną wpływom nurtów etyk nieantropocentrycznych albo skrajnie antropocentrycznych ${ }^{14}$. Redefinicja kategorii rodziny nie jest jedynym przykładem. W perspektywie realizacji celów zrównoważonego rozwoju zmiana znaczenia dotyczy wielu symboli kultury chrześcijańskiej. Egzemplifikacją takich procesów może być m.in. działalność skandynawskiej firmy Ikea, która realizując cele zrównoważonego rozwoju, proponowała nazywać „Boże Narodzenie” „zimową imprezą”, a „choinkę” „rośliną sztuczną do wewnątrz” ${ }^{15}$. Z jednej strony studia nad ideologią zrównoważonego rozwoju pozwalają wskazać obszary posthumanizmu wyzwalającego byty zwierzęce

12 Zob. M. Gierycz, Europejski spór o człowieka, Warszawa 2017, s. 274-277.

13 Zob. M. A. Peeters, Globalizacja zachodniej rewolucji kulturowej, Warszawa 2010, S. 192.

14 Por. A. Ganowicz-Bączyk, Etyka środowiskowa, w: Etyka. Część II. Filozoficzna etyka życia spełnionego, red. S. Janeczek, A. Starościc, Lublin 2016, s. 181-208.

15 Polskie Radio 24, „Zimowa impreza” zamiast Bożego Narodzenia w Ikei, https:// polskieradio24.pl/5/1223/Artykul/2398997,Zimowa-impreza-zamiast-BozegoNarodzenia-w-Ikei?fbclid=IwAR3Lot K2JPjHмvCa4UsAGVE3GHngi_HU7B6s7z7Moimzpkinjj2SndwaL8k (6.11.2019). 
i roślinne, afirmując je. $Z$ drugiej strony odsłaniają ujęcia ekofeminizmu upodabniającego kobiety i zwierzęta w kulturze patriarchalnej ${ }^{16}$.

Nowa kultura wyrażająca się niekiedy w postulatach marginalnych środowisk społecznych stoi w opozycji do tożsamości aksjologicznej ładu społecznego, potwierdzonej w preambule do Konstytucji i wyrażającej się w ładzie prawnym - ordo iuris. Złożony charakter normatywny rzeczywistości społecznej pozwala harmonijnie łączyć ją z życiem społecznym, którego dynamika zmian współgra z aktywnością naukową opierającą się na analizie współczesnych problemów pluralistycznych społeczeństw. Stąd nauki społeczne przy wykorzystaniu metod socjologicznych czerpią inspirację z analiz systemów normatywnych. Powołując się na analizę społeczno-prawną Rozalii Kielmans-Ratyńskiej z Instytutu na rzecz Kultury Prawnej dot. interpretacji Agendy 2030, zauważa się umniejszenie statusu małżeństwa poprzez redefinicję tego związku i podważanie jego naturalnego charakteru wyrażającego się w relacji osób odmiennej płci ${ }^{17}$. Agenda Zrównoważonego Rozwoju 2030 wraz ze swoim politycznym naciskiem wzbudza również kontrowersje z powodu nieuzasadnionego przyjmowania wskaźników w zakresie tzw. zdrowia seksualnego i reprodukcyjnego. Chociaż cele zrównoważonego rozwoju są ukierunkowane na ludzi poprzez eliminację ubóstwa czy zapewnienie dobrobytu gospodarczego, to jednak zdaniem Kielmans-Ratyńskiej nie pojawiają się adekwatne sformułowania definiujące rodzinę jako podstawową grupę społeczną. Wydaje się, że pominięcie pierwotnej socjalizacyjnej - funkcji rodziny marginalizuje tę wspólnotę osób również we wtórnych procesach socjalizacyjnych, wyrażających się

16 Por. Zwierzęta, gender, kultura. Perspektywa ekologiczna, etyczna i krytyczna, red. M. Dąbrowska, A. Barcz, Lublin 2014.

17 Zob. R. Kielmans-Ratyńska, Agenda 2030 - przyszłość bez rodziny, https://ordoiuris.pl/rodzina-i-malzenstwo/agenda-2030-przyszlosc-bez-rodziny (28.11.2019). 
w kształtowaniu osobowości młodych ludzi i tworzeniu uwarunkowań rozwoju, ich relacyjności względem siebie nawzajem. Pomijanie podstawowych funkcji rodziny kontrastuje z postulatami równości płci i wydaje się umniejszać rolę rodziny, pozbawiając ją tradycyjnie przypisanych jej zadań socjalizacyjnych.

$\mathrm{W}$ realizacji celów zrównoważonego rozwoju ujmowanych w perspektywie globalnej pośród wielu teorii i poglądów na temat rodziny niezrozumiała jest marginalizacja tej podstawowej grupy społecznej w życiu społecznym. Na marginalizację rodziny wpływa przyjmowana koncepcja człowieka. Ideologia zrównoważonego rozwoju wydaje się wpisywać w posthumanistyczną optykę rehabilitującą zwierzęta, rośliny i byty nieożywione. Ekologiczne ujęcia zrównoważonego rozwoju nadają bytom nieludzkim status podmiotowy, rezygnując jednocześnie $z$ antropocentryzmu i centralnego pozycjonowania człowieka, który w nurcie posthumanizmu nie jest odrębnym gatunkiem $^{18}$. Posthumanistyczna optyka zmienia koncepcję rodziny w modelu zachodnioeuropejskim, redukując liczebność tej grupy społecznej. Na podstawie aktów normatywnych powolnej zmianie ulega złożoność płciowa na poziomie małżeństwa, które z działaniach redefinicyjnych ujmuje się tylko jako związek partnerski. Podstawowym motywem zakładania rodzin w kształtowanej kulturze posthunamistycznej staje się czynnik emocjonalny - reprodukcja schodzi na dalszy plan realizacji więzi małżeńskiej czy partnerskiej. Dbałość o emocjonalny komfort w posthumanistycznych społeczeństwach dopełnia troska człowieka o zwierzęta i środowisko naturalne ${ }^{19}$.

18 Por. H. Mamzer, Posthumanizm we współczesnych modelach rodzin: zwierzęta jako członkowie rodziny?, w: Rodzina wobec wyzwań współczesności, red. I. Taranowicz, S. Grotowicz, Wrocław 2015, s. 153.

19 Por. H. Mamzer, Posthumanizm we współczesnych modelach rodzin: zwierzęta jako członkowie rodziny?, dz. cyt., s. 153. 


\section{Status zasady zrównoważonego rozwoju i jej zastosowanie - transmisja wartości}

Naczelnym stanem rządzącym człowiekiem w ramach jego struktury wewnętrznej i osobowości jest potencjalność. Na zewnątrz człowiek wyraża się w działaniu i przyjmowanych postawach, pośród których nie można zapomnieć o komponencie społeczno-etycznym. Naturę ludzką rozpatruje się w podwójnym aspekcie: ogólnym i jednostkowym. Sens ogólny mówi o gatunkowej charakterystyce osoby ludzkiej, która jest niezmienna i jednakowa dla wszystkich ludzi (in actu primo). W sensie indywidualnym (in actu secundo) natura ludzka jest zmienna, rozwija się w zależności od uwarunkowań miejsca i czasu. Wszechstronność rozwoju zależy m.in. od bogactwa życia społecznego, które pomaga człowiekowi osiągać wyższy stopień doskonałości. Podstawową grupą społeczną jest rodzina, ale oprócz niej występuje szereg społeczności przyczyniających się do rozwoju fizycznego, psychicznego, intelektualnego, kulturowego czy duchowego jednostki społecznej. Tworzeniu takich uwarunkowań odpowiada zasada dobra wspólnego, która we współzależności z zasadą pomocniczości i solidarności tworzy system principiów społecznych zabezpieczających podstawowe komórki życia społecznego, wzmacniając je przy zastosowaniu zasad o charakterze szczegółowym. Szerokie uwarunkowania wpływające na kondycję rodziny i wartości $\mathrm{z}$ nią korelujące w wąskich zakresach realizacji polityk ogniskują się wokół życia społeczno-gospodarczego. Transmisja wartości przy zastosowaniu systemu podstawowych zasad etyczno-społecznych sprawia, że rodzinę ujmuje się $\mathrm{w}$ jednoznacznie zdefiniowanym układzie odniesienia podstawowych wartości ${ }^{20}$. U źródeł transmisji

20 Por. J. Turowski, Socjologia. Małe struktury społeczne, Lublin 2001, s. 115-128. 
wartości podporządkowanych zasadom etyczno-społecznym jest jednorodny, personalistyczny system aksjonormatywny, z którego wyrasta kultura chrześcijańska ${ }^{21}$.

Jedną ze szczegółowych zasad etyczno-społecznych jest zasada zrównoważonego rozwoju, która w zakresie aksjologicznym mówi o realizacji polityk zrównoważonego rozwoju w duchu antropocentryzmu umiarkowanego. Zastosowanie tej zasady szczegółowej niesie ze sobą ważne implikacje. Odnosi działanie społeczne do podstawowych zasad etyczno-społecznych i sprawia, że transmisja wartości odwołuje się do antropologii personalistycznej, odcinając się od nurtów nieantropocentrycznych, pośród których znajdują się orientacje biocentryczne, fizjocentryczne, patocentryczne i ekocentryczne. Analiza transmisji wartości rodziny w kontekście realizowanych polityk środowiskowych pozwala stwierdzać, że personalistyczne ujęcie działań w obszarze społeczno-gospodarczym sytuuje człowieka w centrum interakcji społecznych niezależnie od jego wieku, ale ze względu na posiadaną godność i podstawowe prawo do życia od poczęcia aż do naturalnej śmierci. Kultura personalistyczna ujmuje nie tylko interakcje, ale relacje osobowe tworzące więzi społeczne. Transmisja wartości wraz z zastosowaniem zasady zrównoważonego rozwoju polega na komunikowaniu światu społecznemu wartości wzmacniających pozycję człowieka, służących jego integralnemu rozwojowi. Odbywa się to w poszczególnych zakresach życia społecznego, w których człowiek i rodzina wraz z szeregiem pozostałych wartości tworzą w obrębie złożonego układu aksjonormatywnego specyficzną, personalistyczną sytuację aksjologiczną. Personalizm dla relacji rodziny z jej otoczeniem, także tym środowiskowym, kształtuje habitus, który konstytuuje rodzinę jako grupę społeczną o podstawowym znaczeniu

21 Por. P. Sztompka, Socjologia. Analiza społeczeństwa, Kraków 2012, s. 315-345. 
dla życia społecznego ze względu na jej pozycję, rolę i szereg funkcji wpływających na całokształt świata społecznego i zmianę społeczno-środowiskową w kontekście ideologii zrównoważonego rozwoju. Przy tak ujmowanej transmisji wartości rodziny małżeństwo pozostaje stałym związkiem mężczyzny z kobietą.

Zasada zrównoważonego rozwoju w dymensji społecznej ma na celu komunikować ów habitus zwłaszcza w perspektywie polityki środowiskowej i restrukturyzacji systemów gospodarczych zmieniających swoją dynamikę i umocowanie zasobowe ze względu na trendy ekologiczne. W życiu gospodarczym wyrażają się one w postulatach przejścia na typ gospodarowania w układzie zamkniętym (circular economy). Personalistyczny habitus rodziny $\mathrm{w}$ transmisji wartości przy realizacji celów zrównoważonego rozwoju stanowi o rezultacie oddziaływań socjalizacyjnych. Zasada etyczno-społeczna zakłada realizację ideału w działaniach na polu polityki rozumianej jako „troska o dobro wspólne" tak, aby rezultatem zastosowania takiej polityki pozostawał personalistyczny układ aksjologiczny. Jest on niezbędny do interioryzowania wartości i norm w rozwoju życia społecznego, a poprzez transmisję wartości zabezpiecza status rodziny w perspektywie międzypokoleniowej. Przy upowszechnianiu trendów ekologicznych odwzorowywanie działań na podstawie personalistycznego układu wartości komunikuje wzorce zachowań, znaki i treści kultury, objaśniając jednocześnie ich znaczenie. Pierre Bourdieu określa ten proces jako przemoc symboliczną i nazywa go mechanizmem reprodukcji kulturowej. Sprowadza się on do socjalizacji rozumianej w sensie oddziaływania przemocy symbolicznej od najmłodszych lat życia we wszystkich środowiskach wychowawczych.

Realizacja celów zrównoważonego rozwoju skłania do analizy złożoności systemowej, tak by odpowiednio modelować politykę państwa w kontekście zachodzących w nim procesów społecznych poddanych niekiedy oddziaływaniu różnych ideologii mogących 
umniejszać wartość osoby ludzkiej. Dla systemów społecznych wydaje się to konieczne w zakresie uwarunkowań mogących zakłócać integralny rozwój człowieka $\mathrm{w}$ perspektywie jego podstawowego środowiska wzrostu, interioryzowania wartości i ich komunikowania. Państwo, stojąc na straży ładu społecznego, ma władzę dokonywania analizy działań ludzkich, tworzenia nakazów i zakazów służących realizacji jednych wartości, a odrzucaniu tych, które mogłyby podnosić ryzyko burzenia ładu społecznego. W perspektywie międzypokoleniowej niesprawiedliwe są uwarunkowania godzące w naturalny charakter rodziny lub marginalizujące ludzi ze względu na kategorię wieku (starość, życie nienarodzone). Dobro wspólne społeczności w wymiarze międzypokoleniowym nie zostanie zrealizowane, gdy mniejsze społeczności - wraz z tą najbardziej podstawową, rodziną - nie zostaną zespolone wokół wspólnego celu, jakim jest dobro i jego rozwój ${ }^{22}$.

\section{Elkonomia dobra wspólnego - aksjologiczny kontekst zrównoważonego rozwoju i rodziny}

Próby wprowadzania zmian semantycznych w odniesieniu do rodziny i towarzyszące temu procesy społeczne związane z pluralizmem wartości budzą niekiedy obawę, że niektóre tradycyjne wartości i chrześcijańskie idee zostaną unieważnione. Tworzące się nowe, coraz bardziej kulturowo pluralistyczne społeczeństwa wymagają od państwa rozważenia potrzeby wypracowania nowych mechanizmów prawnych i ekonomicznych umożliwiających bardziej jednorodne rozumienie

22 Por. W. Piwowarski, Rodzina jako społeczność naturalna według św. Tomasza $z$ Akwinu, „Roczniki Filozoficzne” 8 (1960) nr 2, s. 99. 
rodziny. Polityka zrównoważonego rozwoju wzmacnia rodzinę, gdy jest ona rozumiana jednorodnie, zwłaszcza w kontekście działań zmierzających do redefinicji tej kategorii społecznej. Jednorodność semantyczna wynikająca $z$ fundamentu antropologicznego utrzymuje w stabilności chrześcijański model rodziny, akcentujący dobro wszystkich jej członków, także tych starzejących się. Wobec narracji proponujących zmianę rozumienia rodziny, jej modelu, struktury i roli w społeczeństwie spójny system zasad etyczno-społecznych ma fundamentalne znaczenie dla utrzymania międzypokoleniowego ładu społeczno-moralnego.

$\mathrm{Z}$ socjologicznego punktu widzenia w realizacji celów zrównoważonego rozwoju kondycja rodziny jest istotna dla zachowania integralności rozwoju społeczno-gospodarczego. Cel społeczności i jej rozwój określa natura społeczna człowieka. Wzmocnienie rodziny $\mathrm{w}$ realizowanej polityce zrównoważonego rozwoju państwa dokonuje się wraz z zaspokajaniem potrzeb rodziny, zapewnieniem warunków zaistnienia życia wraz z troską o jego właściwy rozwój na każdym etapie życia. Wzmocnienie wartości rodziny i zachowanie stabilności tej podstawowej grupy społecznej zależy zatem od odpowiednich uwarunkowań społecznych, wyzwalających w człowieku siłę zdolną tak ją ukierunkowywać, by realizacja tej wartości przynosiła korzyść zarówno jednostce, jak i społeczności. Polityka zatem wzmacnia rodzinę, kiedy zapewnia jej możliwość zrodzenia potomstwa, jego utrzymanie i wychowanie przy zachodzących jednocześnie procesach zmian demograficznych. Wzmocnienie rodziny dokonuje się wraz z odpowiednią polityką względem osób starszych, których udział w polskim społeczeństwie rośnie. Prognozuje się, że liczba ludności w wieku 80 lat i więcej w skali Polski wzrośnie do roku 2050 z 1,5 mln do 3,5 mln. Przy wzrastającej liczbie osób starszych i wraz z procesem podwójnego starzenia się wsparcia będą potrzebować nie tylko sześćdziesięciolatkowie, lecz także osiemdziesięciolatkowie, osoby chore, 
samotne i niepełnosprawne ${ }^{23}$. Wzmocnienie rodziny dokonuje się w polityce społecznej w oparciu o koncepcję praw człowieka.

Polityka zrównoważonego rozwoju $\mathrm{w}$ realizacji sustainable development goals z punktu widzenia etyki społecznej ukierunkowana jest na realizację ideału rozwoju integralnego, co sprzężone jest $z$ tworzeniem uwarunkowań społeczno-gospodarczych zmierzających do niwelowania dysproporcji rozwojowych. W wyniku procesów demograficznych zachodzących w poszczególnych państwach wsparcie rodziny może dokonać się wraz z systemowym działaniem adresowanym do ludności we wszystkich etapach życia. Niezbędna ku temu jest infrastruktura instytucjonalna państwa, które może łagodzić przeżywanie starości dostępem do personelu opieki społecznej i tworzeniem ośrodków przeznaczonych dla ludzi starszych obciążonych niekiedy nie tylko wiekiem, lecz także niepełnosprawnością. Odpowiednia polityka środowiskowa powiązana $z$ funkcjonowaniem instytucji pomocowych adresowanych do takiej kategorii ludzi stanowi istotne wsparcie w poszczególnych etapach starzenia się.

W koncepcji zrównoważonego rozwoju kategoria rodziny nie występuje bezpośrednio jako wartość znacząca dla osiągania celów tego rozwoju, niemniej jednak jest obecna pośrednio. Koncepcja bowiem wskazuje działania wpisujące się w uwarunkowania społeczno-gospodarcze, które rodzina w różnych zakresach życia gospodarczego sama wykorzystuje, pozostając ważnym podmiotem wpływającym na kreację otoczenia społeczno-środowiskowego. W realizacji polityk transmisja wartości rodziny domaga się nadawania sensu życia na etapie starczym tak, by życie w starości można było twórczo przeżywać.

23 Por. M. Adamczyk, Specyfika procesów starzenia się społeczeństwa polskiego w kontekście wskaźników zrównoważonego rozwoju, w: Wybrane problemy społeczne. Teraźniejszość - przyszłość, red. E. Grudziewska, M. Mikołajczyk, Warszawa 2018, s. 120. 
Zasada zrównoważonego rozwoju tworzy wówczas personalistyczną sytuację aksjologiczną, w której człowiek na każdym etapie życia jest kluczową wartością, a uwarunkowania środowiskowe mają mu służyć do optymalizacji jego rozwoju psychosomatycznego.

W realizacji celów zrównoważonego rozwoju prace instytucji społecznych wspomaga ekonomia dobra wspólnego ${ }^{24}$. Jest to model strategii organizacji pracy włączający 20 najbardziej znaczących obszarów działania instytucji społecznych pogrupowanych według istotnych wartości, wśród których pierwszą i podstawową jest godność ludzka. Bilans dobra wspólnego pozwala ukierunkować działania instytucji według systemu zasad etyczno-społecznych. Realizacja tej strategii ma na celu tworzyć personalistyczny układ aksjologiczny, w którym wartość rodziny jest chroniona ze względu na godność ludzką. Strategia włącza jeszcze kategorie solidarności i sprawiedliwości, przy jednoczesnej realizacji ekologicznych celów zrównoważonego rozwoju. W bilansie dobra wspólnego znaczącą wartość zyskuje również przejrzystość i współdecydowanie. Marginalizację wartości rodziny i otoczenia społecznego wskutek ekologicznej nadinterpretacji zrównoważonego rozwoju niweluje się w dowartościowywaniu znaczenia instytucji społecznych. Ekonomia dobra wspólnego pozwala realizować cele rozwoju zrównoważonego, mając na uwadze obszar gospodarczy, w którym członkowie rodziny odnajdują się w różnych zakresach wiekowych. W instytucjonalizacji pracy socjalnej według wyszczególnionych kryteriów dobra wspólnego wzmocnienie rodziny może dokonać się w obszarach: dostawcy usług w organizacji pomocy społecznej, zarządzania własnością, relacji z partnerami finansowymi, współpracy z podmiotami wspomagającymi instytucje pracy socjalnej,

24 Por. M. Kasper, G. Hofielen, Punkten für das Gemeinwohl und die Sustainable Development Goals, Berlin 2019. 
klientów pracy socjalnej i ich rodzin. Strategię przewidzianą do realizacji celów zrównoważonego rozwoju można zaadresować do instytucji pomocy społecznej i współpracujących z nimi podmiotów.

\section{Zakończenie}

Koncepcja zrównoważonego rozwoju może wzmacniać rodzinę wyłącznie w powrocie do rozumienia polityki jako „roztropnej troski o dobro wspólne". Dobro wspólne zakotwiczone jest w systemie zasad etyczno-społecznych, którego podstawową kategorią jest rodzina rozumiana jako podstawowa komórka życia społecznego. Jednorodność definicji rodziny, zwłaszcza w ujęciach prawa, oraz prawidłowa antropologia społeczna w realizacji celów zrównoważonego rozwoju stają się głównymi płaszczyznami odniesienia wobec niezrozumiałych prób redefinicji podstawowych kategorii społecznych, w tym rodziny. $\mathrm{Na}$ straży realizacji polityk zrównoważonego rozwoju stoi zasada zrównoważonego rozwoju. Jej celem jest opis zastanej rzeczywistości społecznej silnie naznaczanej trendami ekologicznymi, następnie ocena etyczna i korekta działań społecznych, mająca na celu realizację zrównoważonego rozwoju w odniesieniu do kategorii dobra wspólnego. Głównie w powrocie do stabilnych punktów odniesienia osadzonych na podstawowych kategoriach wchodzących w zakres ideowy personalizmu chrześcijańskiego rodzina wobec zmieniających się trendów kulturowych i demograficznych ma szansę zachować swoje znaczenie i odpowiednio wypełniać wynikające z jej natury zadania. Wzmocnienie rodziny następuje wraz z dostrzeżeniem potrzeb rozwoju ludzi wszystkich kategorii wiekowych w przestrzeni życia rodzinnego, zarówno tych najmłodszych, nawet jeszcze nienarodzonych, jak i tych najstarszych, może już częściowo zmarginalizowanych ze względu na proces starzenia się. Kategoria ludzi w tzw. wieku produkcyjnym, poddana czynnikom ekonomicznym, staje się kluczowa 
dla integralnego rozumienia wartości rodziny. Procesy socjalizacyjne w głównej mierze zależne są od rozumienia wartości, identyfikacji z nimi i w konsekwencji - ich realizacji. W tych zależnościach z jednej strony nauki społeczne silnie korelują z normami prawa, $\mathrm{z}$ drugiej strony normy prawne w życiu społecznym wynikają z zauważanych nieprawidłowości w organizacji życia społecznego.

\section{Streszczenie}

Opracowanie ma na celu ukazać transmisję wartości rodziny w procesie realizacji zrównoważonego rozwoju. Najpierw dokona się rozróżnienia pomiędzy ideą, polityką a zasadą etyczno-społeczną w kontekście kategorii zrównoważony rozwój. Następnie wskaże się wartość rodziny w perspektywie analizy społeczno-prawnej dotyczącej realizacji celów zrównoważonego rozwoju, po czym przejdzie się do przedstawienia statusu zasady zrównoważonego rozwoju i jej zastosowania. Narrację zogniskuje się wokół odpowiedzi na pytanie: jak realizacja zrównoważonego rozwoju może wzmacniać rodzinę? Jedną z możliwości jest program ukierunkowania celów zrównoważonego rozwoju na koncepcję dobra wspólnego. Niezbędny jest do tego spójny system zasad etyczno-społecznych, w oparciu o który można tworzyć strategie rozwoju społeczno-gospodarczego. Dla egzemplifikacji takiego działania przedstawi się ramowy program takiej strategii, którą wypracowali Matthias Kasper i Gerd Hofielen.

Słowa kluczowe: zrównoważony rozwój, zasada etyczno-społeczna, transmisja wartości, rodzina

\section{Summary}

Transmission of family values in the perspective of the implementation of sustainable development

The aim of the study is to show the transmission of family values in the process of implementing sustainable development. First, a distinction will be made between the idea, policy and ethical and social principle in the context of the category of sustainable development. Then, the value of the 
family will be indicated in the perspective of the socio-legal analysis of the implementation of the sustainable development goals, and then the status of the principle of sustainable development and its application will be presented. The narrative will focus on the answer to the question: how can the implementation of sustainable development strengthen the family? One possibility is a program of focusing the SDGs on the concept of the common good. For this, a coherent system of ethical and social principles is necessary, on the basis of which strategies for social and economic development can be created. To exemplify such action, the framework program of such a strategy, developed by Matthias Kasper and Gerd Hofielen, will be presented. Keywords: sustainable development, ethical and social principle, transmission of values, family 